\title{
HUBUNGAN PENGETAHUAN PERAWAT DALAM DOKUMENTASI KEPERAWATAN DENGAN PELAKSANAAN DI RUMAH SAKIT
}

\author{
ANISYAH ISWARA
}

\author{
anisyahiswara@gmail.com
}

\section{LATAR BELAKANG}

Dokumentasi Asuhan Keperawatan merupakan informasi tertulis tentang status dan perkembangan kondisi klien serta semua kegiatan asuhan keperawatan yang dilakukan oleh perawat (Fisbach,1991). Nursalam ( 2008) mengatakan instrument studi dokumentasi penerapan standar asuhan keperawatan di Rumah Sakit menggunakan instrument A dari DEPKES (1995) yang meliputi standar I (Pengkajian Keperawatan), standar II (Diagnosa Keperawatan), standar III (Perencanaan Keperawatan), standar IV (Intervensi Keperawatan), standar V (Evaluasi Keperawatan), standar VI (Catatan Asuhan Keperawatan). Dokumentasi keperawatan mempunyai makna penting dalam aspek hukum, kualitas pelayanan, komunikasi, pendidikan, penelitian, dan akreditasi. Berkaitan dengan perlindungan hukum, dokumentasi asuhan keperawatan dapat memberi bukti yang berharga tentang kondisi pasien dan pengobatannya dan dapat bersifat kritis dalam menentukan standar perawatan apakah telah dipenuhi atau tidak (Nursalam, 2008). Dokumentasi asuhan keperawatan dapat digunakan sebagai tanggung jawab dan tanggung gugat dari berbagai kemungkinan masalah yang dialami oleh pasien atau klien baik masalah kepuasan maupun ketidakpuasan terhadap pelayanan kesehatan yang diberikan (Nursalam,2001). Dokumentasi asuhan keperawatan yang tepat waktu, akurat dan lengkap tidak hanya penting untuk melindungi perawat tetapi penting juga untuk membantu pasien atau klien mendapat asuhan keperawatan yang lebih baik (Depkes RI,1996).

Pelaksanaan dokumentasi keperawatan sebagai salah satu alat ukur untuk mengetahui, memantau dan menyimpulkan suatu pelayanan asuhan keperawatan yang diselenggarakan di rumah sakit (Fisbach,1991 dalam Setiadi,2012). Rendahnya pelaksaanaan dokumentasi keperawatan dipengaruhi tiga faktor individu (karakteristik perawat) yang meliputi pendidikan, umur, jenis kelamin, masa kerja dan pengetahuan, sedangkan faktor psikologis misalnya motivasi dan faktor organisasi (Gibson dan Ivancevich,2002 dalam Nursalam,2003)

Hubungan pengetahuan perawat sangat mempengaruhi dalam pelaksanaan dokumentasi keperawatan di rumah sakit. Perawat dengan tingkat pengetahuan yang berbeda akan mempunyai kualitas dokumentasi yang berbeda pula, Karena semakin tinggi tingkat pengetahuan seorang perawat maka semakin mudah untuk membuat keputusan dalam melakukan pelaksanaan dokumentasi keperawatan serta dapat meningkatkan motivasi, keinginan dan kematangan intelektual dalam penerapan dokumentasi secara lengkap ,selain itu tingkat pengetahuan yang 
tinggi dapat menyebabkan seorang perawat lebih mampu dan bersedia menerima tanggung jawab .Hal ini akan mempengaruhi kelengkapan komponen dokumentasi keperawatan. Komponen dokumentasi keperawatan meliputi komponen isi dokumentasi dan komponen dalam konsep penyusunan dokumentasi. Komponen isi dokumentasi meliputi: pengkajian, diagnosis keperawatan, rencana keperawatan, pelaksanaan tindakan keperawatan, evaluasi, pengesahan (tanda tangan/paraf dan nama terang perawat), dan catatan keperawatan diisi secara lengkap dan jelas, resume keperawatan (Catatan pasien pulang atau meninggal dunia).

Berdasarkan latar belakang tersebut dapat disimpulkan bahwasannya masalah pada pengkajian ini merupakan Hubungan Pengetahuan Perawat Dalam Dokumentasi Keperawatan Dengan Pelaksanaan di Rumah Sakit.

\section{METODE}

Metode yang digunakan adalah metode penelusuran buku teks, jurnal ,google scholar, buku referensi, yaitu dengan cara sistem "Literature Review" dimana maksudnya dengan cara mengumpulkan beberapa data,menganalisis dan melakukan pengkajian dengan menggunakan jurnal, buku teks, google scholar yang berfokus pada metode pembelajaran yang terkait dengan hubungan pengetahuan perawat dalam dokumentasi keperawatan dengan pelaksanaan di rumah sakit serta melakukan eksplorasi dan kajian bebas dengan menggunakan kata kunci Pengetahuan Perawat, Pendokumentasian Asuhan Keperawatan. Sehingga jurnal, text book, google scholar yang digunakan dalam pengkajian dapat digunakan untuk mengetahui bagaimana hubungan pengetahuan perawat dalam dokumentasi dengan pelaksanaan di rumah sakit serta mengetahui bagaimana tingkat pengetahuan perawat dalam dokumentasi keperawatan dengan pelaksanaan di rumah sakit, yang digunakan untuk menerapkan tanggung jawab dan tanggung gugat dari berbagai kemungkinan masalah yang dialami oleh pasien atau klien baik terkait masalah kepuasan maupun ketidakpuasan terhadap pelayanan kesehatan yang diberikan.

\section{HASIL}

Dari beberapa tinjauan literature menyebutkan bahwa adanya hubungan pengetahuan perawat dalam dokumentasi keperawatan dengan pelaksanaan di rumah sakit, Pengetahuan seorang perawat sangat mempengaruhi dalam pelaksanaan dokumentasi asuhan keperawatan. Karena semakin tinggi tingkat pendidikannya maka kemampuan kognitif dan ketrampilannya akan semakin meningkat serta seorang perawat semakin mudah untuk menerima informasi sehingga mampu membuat keputusan dalam melakukan dokumentasi asuhan keperawatan dengan pelaksanaan di rumah sakit, selain itu tingkat pengetahuan perawat yang tinggi akan meningkatkan motivasi, keinginan dan kematangan intelektual dalam pelaksanaan dokumentasi secara lengkap dan tingkat pengetahuan perawat yang tinggi pada umumnya bisa menyebabkan seseorang perawat lebih mampu dan bersedia menerima tanggung jawab. 


\section{PEMBAHASAN}

Asuhan keperawatan yang diberikan perawat kepada pasien dimulai dari memahami konsep dasar keperawatan tentang teori dari ilmu keperawatan kemudian melakukan pengkajian dan riwayat pasien, perencanaan yang terdiri dari (penegakan diagnosis keperawatan, penentuan target sasaran, dan perencanaan keperawatan), pelaksanaan, dan yang terakhir evaluasi atau penilaian yang berkelanjutan. Pendokumentasian merupakan unsur pokok dalam tugas dan tanggung jawab hukum setelah melakukan tindakan keperawatan kepada pasien. pendokumentasian yang baik mempunyai ciri-ciri berdasarkan fakta, data yang akurat, kelengkapan, ringkas, terorganisasi, ketepatan waktu, mudah untuk dibaca.

Dokumentasi merupakan catatan otentik dalam penerapan manajemen asuhan keperawatan profesional. Perawat profesional diharapkan dapat menghadapi tuntutan tanggung jawab dan tanggung gugat terhadap segala tindakan yang dilaksanakan. Kesadaran masyarakat terhadap hukum semakin meningkat sehingga dokumentasi yang lengkap dan jelas sangat dibutuhkan. Komponen penting dalam pendokumentasian adalah komunikasi, proses keperawatan dan standar asuhan keperawatan. Efektifitas dan efisiensi sangat bermanfaat dalam mengumpulkan informasi yang relevan serta akan meningkatkan kualitas dokumentasi keperawatan. Dokumentasi keperawatan adalah bukti pencatatan dan pelaporan yang dimiliki perawat dalam catatan perawatan yang berguna untuk kepentingan klien, perawat dan tim kesehatan dalam memberikan pelayanan kesehatan dengan dasar data yang akurat dan lengkap secara tertulis sebagai tanggung jawab perawat (Wahid \& Suprapto,2012). Dokumentasi asuhan keperawatan yang berkualitas harus terdapat unsur keakuratan, kelengkapan, dan kerelevananan. Kegiatan dokumentasi keperawatan yang tidak lengkap dalam pendokumentasian, keakuratan dan tidak relevan maka akan terjadi kesulitan dalam melakukan pembuktian tindakan yang sudah dilaksanakan dengan baik dan benar. Dokumentasi adalah segala sesuatu yang tercetak atau tertulis yang dapat di andalkan sebagai catatan bukti bagi individu yang berwenang (Potter,2006). Tujuan dokumentasi asuhan keperawatan adalah sebagai alat komunikasi antara klien, keluarga, tim perawat dan tim kesehatan lain sehingga terbentuk komunikasi yang baik dalam perawatan klien, sebagai tanggung jawab dan tanggung gugat perlindungan klien dalam pelayanan dan keamanan perawat dalam memberikan asuhan keperawatan, sebagai informasi statistik acuan perencanaan kebutuhan sarana prasarana dan sumber daya manusia di masa mendatang, sebagai sarana pendidikan yang dapat dijadikan media belajar bagi mahasiswa dan bahan penelitian dalam pengembangan ilmu keperawatan, sebagai sumber data dalam audit keperawatan untuk alat ukur dalam penilaian kinerja perawatan, sebagai dokumen yang bisa dijadikan aspek legal dan bukti autentik bagi perawat ketika menghadapi masalah hukum, sebagai jaminan kualitas pelayanan kesehatan dan pelayanan keperawatan (Setiadi,2012).Pelaksanaan dokumentasi keperawatan sebagai salah satu alat ukur untuk mengetahui, memantau dan menyimpulkan suatu pelayanan asuhan keperawatan yang diselenggarakan di rumah sakit (Fisbach,1991 dalam Setiadi,2012).Salah satu idikator kinerja perawat dalam melaksanakan asuhan keperawatan bisa dilihat dari pelaksanaan pendokumentasian asuhan. Tanpa dokumentasi keperawatan maka semua implementasi 
keperawatan yang telah dilakukuan oleh perawat tidak mempunyai makna dalam hal tanggung jawab dan tanggung gugat (Marrelli,2007).

Manfaat Dokumentasi Asuhan Keperawatan mempunyai makna yang penting dalam berbagai aspek, yaitu aspek kualitas pelayanan karena pendokumentasian memberi kemudahan dalam memberikan pelayanan dan penyelesaian masalah klien sebagai acuan evaluasi untuk meningkatkan mutu pelayanan, aspek komunikasi dan sebagai sarana komunikasi antara perawat dengan klien atau keluarga, tenaga kesehatan lain sehingga dapat membentuk suatu koordinasi yang baik dan tidak terjadi duplikasi yang tidak efektif dan efisien, aspek hukum sebagai dokumen resmi dan bernilai hukum atau legalitas dalam sistem pelayanan keperawatan sehingga apabila terjadi suatu masalah hukum maka dokumentasi dapat dijadikan sebagai barang bukti di pengadilan, aspek pendidikan dan pelatihan dokumentasi mempunyai nilai pendidikan karena isinya menyangkut kronologis dari kegiatan asuhan keperawatan yang dapat dijadikan sebagai referensi pembelajaran bagi peserta didik profesi keperawatan, aspek keuangan semua asuhan keperawatan yang belum, sedang atau telah diberikan didokumentasikan yang dapat dijadikan acuan atau pertimbangan biaya bagi klien, aspek penelitian dapat dijadikan sebagai bahan atau objek riset dan pengembangan profesi keperawatan,aspek akreditasi pendokumentasian asuhan keperawatan sebagai indikator dalam penilaian suatu pelayanan keperawatan dalam akreditasi rumah sakit (Nursalam,2007). Prinsip-prinsip yang harus diperhatikan dalam dokumentasi asuhan keperawatan antara lain dokumentasi harus dilakukan segera setelah pengkajian pertama dilakukan atau pada tiap langkah asuhan keperawatan, catat setiap respon pasien keluarga tentang informasi atau data yang penting, pastikan kebenaran setiap data-data yang akan dicatat, data harus objektif bukan data penafsiran perawat, dokumentasikan bila terjadi perubahan kondisi atau timbul masalah baru, hindarkan dokumentasi yang baku karena setiap pasien mempunyai masalah yang berbeda, hindari penggunaan istilah penulisan yang tidak jelas dalam pencatatan harus disepakati dan atas kebijakan institusi, data harus ditulis dengan tinta bukan pensil agar tidak mudah dihapus, bila terjadi kesalahan dalam penulisan dicoret dan ganti dengan yang benar kemudian ditanda tangani, setiap dokumentasi cantumkan waktu, tanda tangan, nama jelas penulis, wajib membaca setiap tulisan dari anggota kesehatan lain sebelum menulis, dokumentasi harus dibuat dengan tepat, jelas dan lengkap (Carpenito,2006).

\section{Tahap-Tahap Pendokumentasian Asuhan Keperawatan}

\section{Dokumentasi Pengkajian Asuhan Keperawatan}

Pengkajian adalah tahap awal dari proses keperawatan dan merupakan proses suatu pengumpulan data yang sistematis dari berbagai sumber untuk mengevaluasi dan mengidentifikasi status kesehatan klien (Lyer et al,1996). Menurut Nursalam (2011), kriteria pengkajian keperawatan meliputi :

\section{Pengumpulan data}

a) Tipe data

Tipe data pada pengkajian keperawatan terdiri dari data subjektif dan data objektif. Data subjektif adalah data yang didapatkan dari klien /pasien sebagai suatu pendapat terhadap suatu situasi dan kejadian, data objektif adalah data yang diobservasi dan diukur oleh perawat. 
b) Fokus pengambilan data

Fokus pengambilan data meliputi riwayat status kesehatan sebelumnya dan saat ini, pola koping yang pernah digunakan dan yang saat ini digunakan, fungsi, status sebelumnya dan saat ini, respon terhadap terapi medis dan intervensi keperawatan, resiko untuk masalah potensial hal-hal yang dapat menjadi dorongan atau kekuatan bagi klien.

\section{Karakteristik Data}

Data yang dikumpulkan untuk menunjang diagnosa keperawatan harus mempunyai karakteristik yang lengkap, akurat, nyata dan relevan.

\section{Sumber Data}

Data-data yang dikumpulkan dapat diperoleh tidak hanya dari klien tetapi dari orang terdekat (keluarga), catatan klien, riwayat penyakit terdahulu, konsultasi dengan terapi, hasil pemeriksaan diagnostik, catatan medis, dan sumber kepustakaan

\section{Dokumentasi Diagnosa Keperawatan}

Diagnosa asuhan keperawatan adalah pernyataan yang menjelaskan status atau masalah kesehatan aktual atau potensial serta penyebabnya (Nursalam,2007). Tahap diagnosa adalah tahap pengambilan keputusan pada proses keperawatan yang meliputi identifikasi apakah maslah klien dapt dihilangkan , dikurangi atau diubah melalui tindakan keperawatan (Nursalam,2007).

Kriteria proses keperawatan meliputi : proses diagnosa terdiri dari atas analisis, interprestasi data, identifikasi masalah, klien dan perumusan diagnosis keperawatan, diagnosa keperawatan terdiri dari atas masalah, penyebab, dan tanda atau gejala, atau terdiri atas masalah dan penyebab, bekerjasama dengan klien, petugas kesehatan lain untuk memvalidasi diagnosa keperawatan, melakukan pengkajian ulang, dan merevisi diagnosa berdasarkan data terbaru (Nursalam2007).

Tujuan diagnosa keperawatan dalam asuhan keperawatan untuk mengidentifikasi masalah adanya respon klien terhadap status kesehatan, faktor yang menunjang atau menyebabkan suatu masalah, kemampuan pasien untuk mencegah atau menyelesaikan masalah, mengkomunikasikan masalah klien pada tim kesehatan, mendokumentasikan tanggung jawab dalam identifikasi masalah, mengidentifikasi masalah utama perkembangan keperawatan (Nursalam,2007).

\section{Dokumentasi Rencana Keperawatan}

Tujuan perencanaan intervensi keperawatan dan aktivitas keperawatan untuk mengurangi, menghilangkan, dan mencegah masalah keperawatan klien. Kriteria proses perawatan membuat rencana tindakan asuhan keperawatan untuk mengatasi masalah dan meningkatkan kesehatan meliputi perencanaan terdiri atas prioritas, tujuan dan rencana tindakan keperawatan, bekerjasama dengan klien dalam menyusun rencana tindakan keperawatan, perencanaan bersifat individual sesuai dengan kondisi atau kebutuhan klien, mendokumentasikan rencana keperawatan (Nursalam,2007).

Tujuan rencana asuhan keperawatan yaitu tujuan administrasi meliputi mengidentifikasi fokus keperawatan individu atau keluarga, membedakan tanggung jawab perawat dengan profesi 
kesehatan lainnya, menyusun kriteria guna pengulangan asuhan keperawatan dan evaluasi, keberhasilan asuhan keperawatan, menyediakan kriteria klasifikasi klien, sedangkan tujuan klinik meliputi suatu pedoman dalam penulisan, mengkomunikasikan asuhan keperawatan yang akan diimplememtasikan dengan perawat lain seperti apa yang akan apa yang harus diobservasi, apa yang akan dilakukan. Menyusun kriteria hasil (outcome) guna pengulangan asuhan keperawatan dan evaluasi keberhasilan asuhan keperawatan, rencana intervensi yang spesifik dan langsung bagi perawat untuk melaksanakan intervensi kepada klien dan keluarganya (Cafenito,2006).

\section{Dokumentasi Implementasi Keperawatan}

Implementasi adalah pelaksanaan dari rencana intervensi untuk mencapai tujuan yang spesifik yaitu membantu klien dalam mencapai tujuan yang telah ditetapkan mencakup peningkatan kesehatan, pencegahan penyakit, pemulihan kesehatan dan mempasilitasi koping (Lyer et al,1999).

Kriteria pengimplementasian tindakan yang telah diidentifikasi dalam rencana asuhan keperawatan meliputi bekerjasama dengan klien dalam pelaksanaan tindakan keperawatan, kolaborasi dengan tim kesehatan lain, melekukan tindakan keperawatan untuk mengatasi kesehatan klien, memberikan pendidikan pada klien dan keluarga mengenai konsep ketrampilan asuhan diri serta membantu klien memodifikasi lengkunganyang digunakan, mengkaji ulang dan merevisi pelaksanaan tidakan keperawatan berdasarkan respon klien (Nursalam 2007).

\section{Dokumentasi Evaluasi Keperawatan}

Evaluasi asuhan keperawatan merupakan fase akhir dari proses keperawatan. Hal-hal yang dievaluasikan adalah keakuratan, kelengkapan, kualitas data, teratasi atau tidaknya masalah klien, dan pencapaian tujuan serta ketepatan intervensi keperawatan (Nursalam,2007)

Kriteria perawat mengevaluasi kemajuan klien terhadap tindakan keperawatan dalam pencapaian tujuan, dan merevisi data dasar dan perencanaan meliputi menyusun perencanaan evaluasi hasil dari intervensi secara komprehensif, tepat waktu dan terus menerus, menggunakan data dasar dan respon klien dalam mengukur perkembangan kearah pencapaian tujuan, memvalidasi dan menganalisis data baru dengan teman sejawat, bekerjasama dengan klien, keluarga untuk memodifikasi rencana asuhan keperawatan, mendokumentasikan hasil evaluasi dan memodifikasikan perencanaan (Nursalam,2007).

Ada dua macam evaluasi yaitu evaluasi formatif, evaluasi yang merupakan hasil observasi dan analisa perawat terhadap respon klien segera pada saat dan setelah intervensi keperawatan dilaksanakan dimana evaluasi ini dapat dilakukan secara spontan dan memberi kesan apa yan terjadi pada saat itu. Evaluasi somatif, yaitu evaluasi yang merupakan rekapitulasi dan kesimpulan dari observasi dan analisis status kesehatan klien sesuai dengan kerangka waktu yang ditetapkan pada tujuan keperawatan (Nursalam,2007).

\section{Ada tiga teknik dokumentasi yang sering digunakan:}

$\checkmark$ SOR (Source Oriented Record) Adalah tehnik dokumentasi yang dibuat oleh setiap anggota tim kesehatan. Dalam melaksanakan tindakan mereka tidak tergantung dengan tim lainnya. Catatan ini cocok untuk pasien rawat inap.

\section{$\checkmark$ Kardex}


Teknik dokumentasi ini menggunakan serangkaian kartu dan membuat data penting tentang klien dengan menggunakan ringkasan problem dan terapi klien yang digunakan pada pasien rawat jalan.

$\checkmark$ POR (Problem Oriented Recor) POR merupakan teknik efektif untuk mendokumentasikan system pelayanan keperawatan yang berorientasi pada masalah klien. Teknik ini dapat digunakan untuk mengaplikasikan pendekatan pemecahan masalah, mengarahkan ide pemikiran anggota tim mengenai problem klien secara jelas.

Sistem POR ini mempunyai 4 komponen: 1). Data dasar Daftar masalahn Rencana awal Catatan perkembangan, 2). Format Dokumentasi. Aziz Alimul (2001) mengemukakan ada lima bentuk format yang lazim digunakan:

1. Format naratif

Merupakan format yang dipakai untuk mencatat perkembangan pasien dari hari ke hari dalam bentuk narasi.

2. Format Soapier

Format ini dapat digunakan pada catatan medic yang berorientasi pada masalah (problem oriented medical record) yang mencerminkan masalah yang di identifikasi oleh semua anggota tim perawat. Format soapier terdiri dari: $\mathrm{S}=$ Data Subjektif Masalah yang dikemukakan dan dikeluhkan atau yang dirasakan sendiri oleh pasien $\mathrm{O}$ = Data Objektif. Tanda-tanda klinik dan fakta yang berhubungan dengan diagnose keperawatan meliputi data fisiologis dan informasi dari pemeriksaan. Data info dapat diperoleh melalui wawancara, observasi, pemeriksaan fisik dan pemeriksaan diagnostic laboratorium. $\mathrm{A}=$ Pengkajian (Assesment) Analisis data subjektif dan objektif dalam menentukan masalah pasien. $\mathrm{P}=$ Perencanaan Pengembangan rencana segera atau untuk yang akan dating dari intervensi tindakan untuk mencapai status kesehatan optimal. I = Intervensi Tindakan yang dilakukan oleh perawat. $\mathrm{E}=$ Evaluasi Merupakan analisis respon pasien terhadap intervensi yang diberikan. $\mathrm{R}=$ Revisi Data pasien yang mengalami perubahan berdasarkan adanya respon pasien terhadap tindakan keperawatan merupakan acuan perawat dalam melakukan revisi atau modifikasi rencana asuhan kepeawatan.

3. Format fokus/DAR

Semua masalah pasien diidentifikasi dalam catatan keperawatan dan terlihat pada rencana keperawatan. Kolom focus dapat berisi : masalah pasien (data), tindakan (action) dan respon (R)

4. Format DAE

Merupakan system dokumentasi dengan konstruksi data tindakan dan evaluasi dimana setiap diagnose keperawatan diidentifikasi dalam catatan perawatan, terkait pada rencana keprawatan atau setiap daftar masalah dari setiap catatan perawat dengan suau diagnose keperawatan. 


\section{PENUTUP}

Dokumentasi merupakan catatan otentik dalam penerapan manajemen asuhan keperawatan profesional. Perawat profesional diharapkan dapat menghadapi tuntutan tanggung jawab dan tanggung gugat terhadap segala tindakan yang dilaksanakan. Kesadaran masyarakat terhadap hukum semakin meningkat sehingga dokumentasi yang lengkap dan jelas sangat dibutuhkan.Salah satu bentuk kegiatan keperawatan adalah dokumentasi keperawatan profesional yang akan tercapai dengan baik apabila sistem pendokumentasian dapat dilakukan dengan benar. Kegiatan pendokumentasia meliputi ketrampilan berkomunikasi, keterampilan mendokumenasikan proses keperawatan sesuai dengan standar asuhan keperawatan. Dokumentasi adalah segala sesuatu yang tercetak atau tertulis yang dapat di andalkan sebagai catatan bukti bagi individu yang berwenang (Potter,2006). Dalam melaksanakannya Perawat harus memahami tentang prinsip, tehnik serta model dokumentasi yang akan diberikan sehingga pendokumentasian akan jauh lebih baik. Dokumentasi adalah bukti pencatatan dan pelaporan yang dimiliki perawat dalam catatan yang berguna untuk kepentingan klien, perawat dan tim kesehatan dalam memberikan pelayanan kesehatan dengan dasar data yang akurat dan lengkap secara tertulis sebagai tanggung jawab perawat (Wahid \& Suprapto,2012). Dokumentasi asuhan keperawatan yang berkualitas harus terdapat unsur keakuratan, kelengkapan, dan kerelevananan Kegiatan dokumentasi keperawatan yang tidak lengkap dalam pendokumentasian, keakuratan dan tidak relevan maka akan terjadi kesulitan dalam melakukan pembuktian tindakan yang sudah dilaksanakan dengan baik dan benar. faktor-faktor yang mempengaruhi dokumentasi asuhan keperawatan memiliki tiga faktor yang mempengaruhi kinerja perawat dalam pendokumentasian yaitu faktor karakteristik individu seperti pendidikan, umur, jenis kelamin, masa kerja dan pengetahuan, sedangkan faktor psikologi misalnya motivasi dan faktor organisasi (Gibson dan Ivancevich,2002 dalam Nursalam 2013). 


\section{DAFTAR PUSTAKA}

1. Nasir, A. (2009). Komunikasi Dalam Keperawatan Dan Aplikasi. Jakarta : Salemba Medika.

2. Potter, A.P., dan Perry, G.A., 2005. Fundamental Keperawatan: Konsep, Proses dan Praktek. Jakarta: Penerbit Buku Kedokteran EGC

3. Retyaningsih Ida yanti dan Bambang Edi Warsito. 2013. Hubungan Karakteristik Perawat, Motivasi, dan Supervisi, Dengan Kualitas Dokumentasi Proses Asuhan Keperawatan, Jurnal Manajemen Keperawatan, 1 (2), 107- 114.

4. Kasim Muhamad dan Muh. Addurrouf. 2016. Peningkatan Kualitas Pelayanan dan Pendokumentasian Asuhan Keperawatan dengan Metode Tim, Nurse Line Journal, 1 (1), 62- 72.

5. Zaidin, A. H. (2009). Dasar-dasar Dokumentasi Keperawatan. Jakarta : EGC

6. Pribadi, A. (2009). Analisis Pengaruh Faktor Pengetahuan, Motivasi dan Persepsi Perawat Tentang Supervisi Kepala Ruang Terhadap Pelaksanaan Dokumentasi Asuhan Keperawatan di Ruang Rawat Inap RSUD Kelet Provinsi Jawa Tengah di Jepara.Semarang:UNDIP

7. Mastini, I G. A. A. P. (2013). Hubungan Pengetahuan, Sikap dan Beban Kerja Dengan Kelengkapan

Pendokumentasian Asuhan Keperawatan Irna di RSUP Sanglah. Denpasar: Fakultas Ilmu Kesehatan Masyarakat Universitas Udayana

8. Damayanti, D. (2013). Buku Pintar Perawat Profesional Teori \& Praktik Asuhan Keperawatan. Yogyakarta: Mantra Book

9. Simamora, R. (2009). Dokumentasi Proses Keperawatan

10. Simamora, R. H., Purba, J. M., Bukit, E. K., \& Nurbaiti, N. (2019). Penguatan Peran Perawat Dalam Pelaksanaan Asuhan Keperawatan Melalui Pelatihan Layanan Prima. JPPM (Jurnal Pengabdian Dan Pemberdayaan Masyarakat), 3(1), 25-31.

11. Nursalam. (2001). Proses dan Dokumentasi Keperawatan: Kosep dan Praktik. Jakarta: Salemba Medika. 